\title{
Flow, food supply and acorn barnacle population dynamics
}

\author{
Eric Sanford*, David Bermudez, Mark D. Bertness"*, Steven D. Gaines \\ Program in Ecology and Evolutionary Biology, Brown University, Providence, Rhode Island 02912, USA
}

\begin{abstract}
While it is widely believed that oceanographic conditions influence benthic filter-feeding organisms, linkages between water column and population processes on rocky shores have been difficult to document. Here we combine laboratory and field studies to explore the relationship between water column conditions and the feeding, growth and population dynamics of the northern acorn barnacle Semibalanus balanoides. $S$. balanoides feeding behavior in a flow tank was strongly dictated by flow speeds, food concentrations, and temperatures. The percentage of barnacles feeding increased with both flow speed and food concentrations, but was depressed at high temperatures. These patterns were accurately reflected in $S$. balanoides feeding in the field. Moreover, within and among populations, variation in barnacle growth over a wide geographic area directly reflected corresponding variation in flow speed, food abundance, and water temperature. Flow effects on barnacles also had conspicuous population consequences. Since barnacle recruitment and growth are both enhanced at high flow speeds, barnacle density-dependent dynamics may often be strongly affected by flow conditions. Our results suggest that water column processes can powerfully affect passive filter feeding organisms on rocky shores and that oceanographic conditions may often leave a strong signature on the distribution, abundance, and dynamics of assemblages of sessile marine organisms.
\end{abstract}

KEY WORDS: Barnacles - Benthic ecology - Filter feeding · Flow speed - Primary and secondary production

\section{INTRODUCTION}

It is widely recognized that environmental conditions play a major role in shaping natural populations, but physical transport processes such as winds and currents are often overlooked as determinants of population and community patterns. In terrestrial plant communities winds can dictate pollen (Tonsor 1985. Bos et al. 1986) and seed dispersal (Fenner 1985) as well as influence local microhabitat conditions (Geiger 1971). For marine filter-feeding organisms, however, transport processes may not only dictate propagule dispersal (Roughgarden et al. 1987) and environmental variation (Valiela 1984, Day et al. 1989), but also strongly influence food supply by dictating food deliv-

\footnotetext{
- Present address: Zoology Department, Oregon State University, Corvallis, Oregon 97331, USA

- Addressee for correspondence
}

ery rates (Vogel 1981, Wildish \& Peer 1983, Okamura 1984). For these organisms linkages between physical transport processes, environmental heterogeneity and population dynamics may be especially strong. The role of these linkages in molding benthic marine assemblages, however, is poorly understood.

Sessile filter-feeding organisms are especially well suited for examining flow effects. Since they do not move as adults, sessile organisms rely on resources from their immediate surroundings, and their performance should reflect local conditions. Flow effects on sessile organisms are probably most pronounced on passive filter feeders since their maximum possible food supply can be envisioned as the product of food concentrations and delivery rates (Eckman et al. 1989b). In addition, since benthic marine assemblages on hard substrates are often space limited (Connell 1961, Jackson 1979), factors that influence their growth likely have important consequences on competitive interactions. 
Recent studies of filter-feeding organisms have focused on the influence of flow on feeding success. These studies assume that flow-related variation in feeding success is simply linked to variation in growth rates and other population processes. Laboratory studies have shown strong flow effects on the settlement (e.g. Eckman 1983, Butman 1987, Pawlik et al. 1991) and growth (e.g. Walne 1972, Okamura 1984, 1992, Cancino \& Hughes 1987, Best 1988) of filter feeders. Recent work has also begun to examine the behavior of near-boundary flows that should ultimately lead to a mechanistic understanding of how fluid dynamics influence benthic processes (Nowell \& Jumars 1984, Butman 1987. Shimeta \& Jumars 1991). Establishing the role of fluid dynamics on growth and population processes in the field, however, has proven to be more difficult (e.g. Sebens 1984, Eckman et al. 1989 a, b). To date, most field investigations of flow effects on the growth and population processes of filter feeders have focused on soft sediment environments where flows are often relatively well behaved and easily characterized (Peterson et al. 1984, Peterson \& Black 1987, Grizzle \& Morin 1989, Gambi et al. 1990, Irlandi \& Peterson 1991). In contrast, on rocky shores where flows are often turbulent, complex and more difficult to characterize, little work has been done linking flow conditions and population processes (Okamura 1992).

The velocities and food concentrations actually seen by small filter feeders on the bottom are not the same as those measured well away from the bottom (Vogel 1981, Nowell \& Jumars 1984). Complex gradients in both velocity and particle concentrations will be established in the turbulent flows characteristic of shallow coastal habitats (Denny 1988, Fréchette et al. 1989, Shimeta \& Jumars 1991). Theoretical and empirical studies of these gradients show that they are affected by both small-scale (e.g. surface topography and organism morphology) and large-scale (e.g. freestream velocities and particle concentrations) processes. Here we focus on conspicuous, easily measured large-scale variation within coastal regions. The issue addressed is whether regional variation in features such as free-stream flow speed, food abundance, and temperature is correlated with corresponding regional variation in the feeding, growth, and population dynamics of benthic filter feeders. Alternatively, the effects of these large-scale components of the flux of particles may be masked by unmeasured differences among sites in the small-scale features that also affect near bottom gradients. If so, simply assaying largescale features, as we do here, will have little explanatory power.

Acorn barnacles are promising organisms to examine linkages between water column dynamics and sessile filter feeders. They have been extensively studied, and we know a great deal about their general biology (see Southward 1987 for a review) and population dynamics (e.g. Connell 1961, Wethey 1983, Gaines \& Roughgarden 1985, Bertness 1989). Moreover, whereas early studies suggested that barnacle growth is enhanced in high flows (Hatton 1938, Crisp 1960), recently we have found that within- and among-site variation in the growth and reproductive output of the northern acorn barnacle Semibalanus balanoides is correlated with variation in both food concentrations and flow patterns (Bertness et al. 1991)

Flow and food supply effects on barnacle feeding and growth have not been well studied under field conditions. Laboratory studies have examined the mechanisms of active barnacle feeding in still water (for review see Anderson \& Southward 1987), but little attention has been paid to barnacle feeding under realistic flow conditions (for an exception see Trager et al. 1990). Studies of barnacle feeding in the field are entirely absent from the literature.

Here we examine the general hypothesis that within- and among-site environmental variation affects the feeding and population biology of the northern acorn barnacle Semibalanus balanoides. Specifically, we: (1) quantify the effects of free-stream flow speed, food concentration, and temperature on barnacle feeding under laboratory conditions; (2) examine within- and among-population patterns in $S$. balanoides feeding and growth in relation to environmental conditions; and (3) explore the potential consequences of flow-driven growth rate and recruitment variation on the dynamics of barnacle populations. Together, our results suggest that the feeding, growth, and population processes of passive filter-feeding organisms on rocky shores may be much more tightly linked to large-scale water column processes than is generally recognized.

\section{METHODS}

Laboratory studies. We designed our laboratory experiments to examine the relative influence of flow speed, water temperature, and food concentrations on Semibalanus balanoides feeding behavior under controlled laboratory conditions. All experiments were run in June and July 1991 in a recirculating flow tank built after the design of Vogel \& LaBabera (1978) with a $18 \mathrm{~cm}$ wide by $18 \mathrm{~cm}$ deep cross-sectional working area.

Unlike laboratory studies of feeding by soft-bottom suspension feeders (for review see Shimeta \& Jumars 1991), our studies were not designed to precisely mimic field flow conditions. In contrast to flows over smooth mud bottoms that may develop an equilibrium 
boundary layer, these barnacles live on very irregular surfaces (large cobbles and boulders) that experience highly irregular, turbulent flows (Denny 1988). Measuring the flow field in such circumstances is difficult, as it would be to simulate it in the laboratory. Instead, we use these laboratory studies simply as a first look at how changes in free-stream flows may alter feeding activity

Free-stream flow speed was monitored with a current meter (Marsh-McBirney model 201), a unidirectional sensor mounted $5 \mathrm{~cm}$ above the flow tank floor in the center of the tank. Current meter readings taken in this way were similar $( \pm 5 \%)$, at all velocities used in our experiments, to free-stream velocities calculated by directly measuring the velocity of neutrally buoyant particles from videos of the tank. As in the field, these free-stream velocities are used as an index of the general flow patterns. Water temperature in the flow tank was thermostatically controlled $\left( \pm 0.1^{\circ} \mathrm{C}\right)$. Barnacles used in the laboratory were haphazardly collected from field populations on flat ( 2 to $4 \mathrm{~cm}$ thick) cobbles from intermediate $(+0.5 \mathrm{~m})$ tidal heights. Two Semibalanus balanoides age classes were examined separately: (1) juveniles, 3 to 4 mo old recruits and (2) adults, $>14$ mo old. These age classes were easily distinguished on the basis of size differences at all sites throughout the study.

The percentage of individuals feeding was used to assay feeding activity. Feeding barnacles were operationally defined as individuals exhibiting full and regular cirral extensions during a 30 s observation period. Once feeding was initiated, individuals tended either to feed continuously for at least several minutes or not at all, so we could easily assess the number of individuals feeding at any given time. The percentage of barnacles feeding was quantified by haphazardly selecting 25 to 50 adult and juvenile barnacles per replicate and scoring them for feeding. We also examined the rate of cirral beat (Crisp \& Southward 1961) in both the laboratory and the field. Cirral beat frequency was found to be independent of flow speed and food concentrations, but dependent on body size and temperature (see Anderson \& Southward 1981 for review). These data will be presented elsewhere.

Flow speed and temperature effects on barnacle feeding. We quantified Semibalanus balanoides feeding over a range of free-stream flow speeds $(0$ to $\left.21 \mathrm{~cm} \mathrm{~s}^{-1}\right)$ and water temperatures $\left(10\right.$ to $\left.25^{\circ} \mathrm{C}\right)$ typically experienced by southern New England (USA) barnacles. Unfiltered seawater from Portsmouth, Rhode Island, USA, was used for all trials. Cobbles from Portsmouth with $S$. balanoides were acclimated for $5 \mathrm{~d}$ to each test temperature in recirculating water baths with Portsmouth seawater before testing. Only cobbles with low (1 ind. $\mathrm{cm}^{-2}$ ) barnacle densities were used to minimize neighbor interference (Okamura 1984), and only barnacles $>3 \mathrm{~cm}$ from the edge of cobbles were scored for feeding to avoid edge effects (Mullineaux \& Butman 1990). Also, all feeding observations were made in the center of the flow tank to minimize wall effects on flows within the tank (Vogel \& LaBarbera 1978).

For each trial, a cobble with barnacles was exposed to aerial conditions at the acclimation temperature for $4 \mathrm{~h}$ to simulate low-tide exposure. The cobble was then placed in the flow tank with fresh seawater and barnacle feeding was quantified during 4 sequential $20 \mathrm{~min}$ periods of increased flow speed. Barnacles were first placed in still water for $20 \mathrm{~min}$, followed by $20 \mathrm{~min}$ each at 3,7 , and finally $21 \mathrm{~cm} \mathrm{~s}^{-1}$. After $5 \mathrm{~min}$ at each flow speed the percentage of adults and juveniles feeding was quantified. Eight replicates were run at each temperature. Food depletion did not appear to influence these trials. The number of barnacles feeding always responded quickly to changes in flow, was relatively constant over all observation periods, and increased strongly in all runs as flow was increased (see 'Results'). Moreover, the feeding of control barnacles run at each flow speed remained constant for at least 90 min at all test temperatures and chlorophyll concentrations were always virtually identical before and after each flow tank feeding trial (unpubl. data).

Food level effects on barnacle feeding. To examine the effect of food concentrations on barnacle feeding barnacles were collected at open coast (Little Compton) and bay (Portsmouth) sites and their feeding activity was examined in water with different food concentrations. Three different water types were tested: (1) Portsmouth water (high chlorophyll concentrations, $2.32 \pm 0.23 \mu \mathrm{g} \mathrm{m}^{-3}$ ), (2) diluted Portsmouth water (low chlorophyll concentrations, $1.18 \pm 0.03 \mu \mathrm{g} \mathrm{m}^{-3}$ ), and (3) unfiltered Little Compton water (low chlorophyll concentrations, $0.39 \pm 0.03 \mu \mathrm{g} \mathrm{m}^{-3}$ ). These treatments were chosen to expose barnacles to water with different chlorophyll concentrations (Bertness et al. 1991) and to test the hypothesis that differences in barnacle feeding activity among sites (see 'Results') were influenced by food concentrations. Diluted Portsmouth water was made to mimic the chlorophyll content of Little Compton water and was prepared by mixing $40 \mathrm{I}$ of filtered (Baxter Grade 362) Portsmouth water with $10 \mathrm{l}$ of unfiltered Portsmouth water. Trials at each food level were run at $20^{\circ} \mathrm{C}$ with a flow speed of $7 \mathrm{~cm} \mathrm{~s}^{-1}$. Sixteen replicates from each site of origin were run at each food level treatment. The percentage of individuals feeding was determined after $20 \mathrm{~min}$. Chlorophyll content of the water used was measured photometrically before each run (see below).

Field studies. We examined Semibalanus balanoides feeding, growth, and population dynamics at 5 south- 


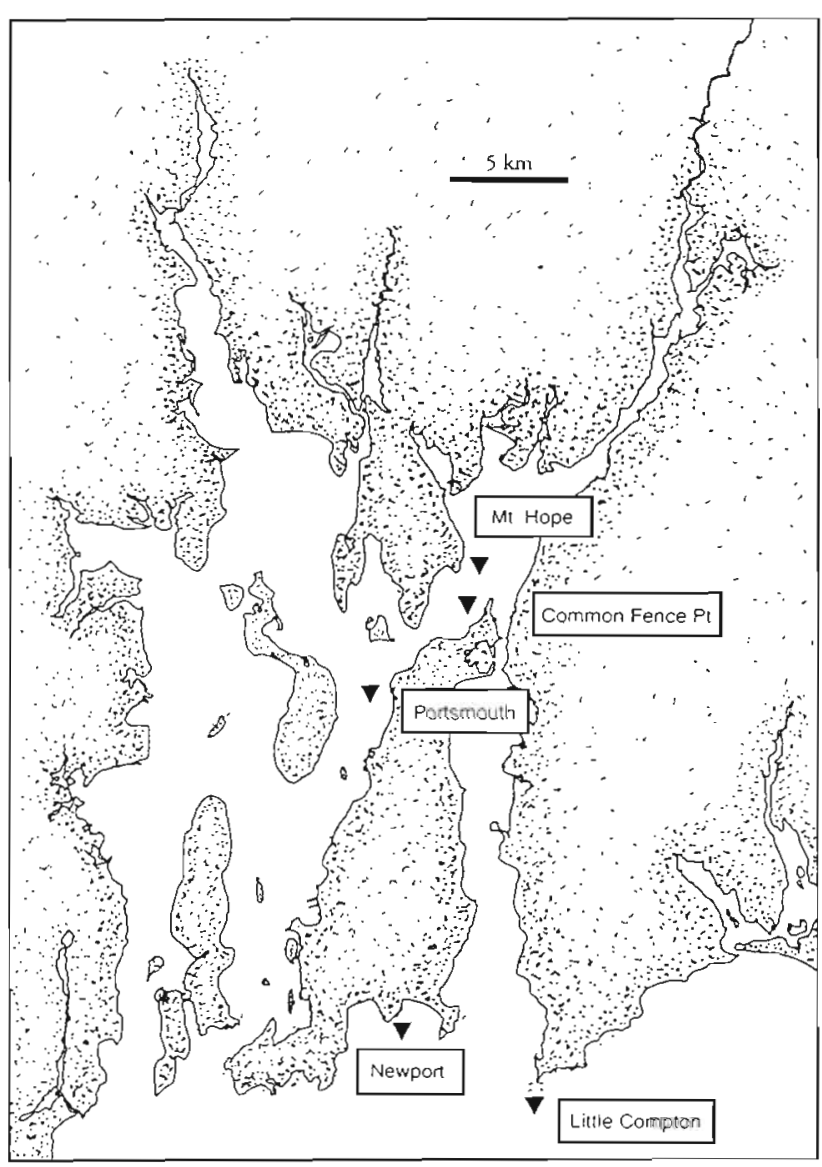

Fig. 1. Narragansett Bay region (Rhode Island, USA) showing the location of the 5 study sites

ern New England locations (Fig. 1) to complement our laboratory studies. The sites were selected to have extreme variation in flow speed and food concentrations (Bertness et al. 1991). Three of the sites were in Narragansett Bay (high food concentrations), and 2 were on the adjacent open coast (low food concentrations). Within Narragansett Bay, 2 of the sites, Common Fence Point and Mt. Hope, were on opposite sides of Mt. Hope Bay and experienced low free-stream flows ( $<5 \mathrm{~cm} \mathrm{~s}^{-1}$ measured $5 \mathrm{~cm}$ above the bottom) and wave action $(<0.5 \mathrm{~m})$. The third bay site, Portsmouth, was situated at a constriction in the estuary and experienced stronger tidal currents (up to $35 \mathrm{~cm} \mathrm{~s}^{-1}$ ). At sites within the bay, tidal currents were responsible for the highest flows observed. Both open-coast sites (Little Compton and Newport) were regularly exposed to high free-stream flows (>40 $\mathrm{cm} \mathrm{s}^{-1}$ ) and heavy waves (up to $3 \mathrm{~m}$ ). At these sites the highest flows observed were always wave generated.

Within each site, we also examined barnacles in high and low-flow habitats. At Mt. Hope and Newport we studied barnacles on seaward (exposed) and landward faces of large boulders. At Common Fence Point and Portsmouth we examined barnacles on large boulders on the shoreline (a low-flow regime) and 5 to $10 \mathrm{~m}$ offshore where flows were consistently higher. At Little Compton, our high-flow habitat was on the waveexposed sicle of a $20 \mathrm{~m}$ wide rock spit whereas the lowflow habitat was on the wave-protected side of the same spit.

Measurement of environmental variables. We characterized environmental conditions within and among field sites by monitoring water movement, food concentrations and temperatures. Our purpose in quantifying these variables was not to determine the precise conditions experienced by feeding barnacles in the field, but simply to quantify gross differences within and among sites that likely are reflected in conditions faced by barnacles. To quantify flow we measured the dissolution of calcium sulfate (dental plaster). The dissolution rate is proportional to flow speed and has been widely used to estimate gross differences in water movement among sites (Opdyke et al. 1987, Eckman et al. 1989a, b, Mullineaux \& Butman 1990, Bertness et al. 1991, Yund et al. 1991). We used chalk cylinders $2 \mathrm{~cm}$ tall with a diameter of $7.5 \mathrm{~cm}$, sealed on the sides and bottom with polyurethane, leaving an erosion surface that remained constant in area as the blocks dissolved. The blocks were glued to wire mesh bases and bolted to rock surfaces in the field. Blocks at all sites were placed at identical low $(0 \mathrm{~m})$ tidal heights to minimize dissolution differences among sites due to variation in rainfall or air temperature while exposed at low tide. Each chalk block was weighed $( \pm 0.01 \mathrm{~g})$ before deployment, and after $5 \mathrm{~d}$ of exposure was dried and reweighed. Every 10 to 14 d from May to September 1991 we quantified chalk dissolution in high- and lowflow habitats at haphazardly selected locations at each site ( 4 blocks site ${ }^{-1}$ exposure ${ }^{-1}$ date $^{-1}$ ). At each site and exposure we also directly measured free-stream flow velocities $5 \mathrm{~cm}$ above barnacle covered surfaces at least every week with a Marsh-McBirney flow meter. These direct measurements of flow velocity were made during all tidal phases over the course of our study.

As a relative measure of food abundance, chlorophyll a concentrations were monitored weekly from May to August 1991. While boundary (or bottom) food concentrations experienced by filter feeders can vary markedly from concentrations in the overlying water column (Wildish \& Kristmanson 1979, Muschenheim 1987a, b, Fréchette et al. 1989), our measurements were made simply to quantify relative differences in potential food concentrations among sites. At each site during high tide we collected three 61 water samples $5 \mathrm{~m}$ offshore over barnacle populations at a depth of $15 \mathrm{~cm}$. Samples were immediately filtered and chlorophyll a concentrations were determined photometri- 
cally (Strickland \& Parsons 1968). Since preliminary estimates of chlorophyll a concentrations were similar in high-and low-flow microhabitats at all study sites, we subsequently sampled chlorophyll in high-flow microhabitats only. Water temperatures (at a depth of $10 \mathrm{~cm}$ ) were also taken at each site on days we sampled chlorophyll.

Barnacle feeding patterns in the field. We examined Semibalanus balanoides feeding in the field at identical tidal heights $(0.5 \mathrm{~m})$ at each field site using SCUBA. On sampling days, feeding observations were made at a single site throughout a tidal cycle. Observations were made ca 30 min after the barnacles were submerged by the incoming tide, ca $30 \mathrm{~min}$ before high tide, and ca 90 min before the barnacles were exposed by the following low tide. Immediately before each observation period, measurements of free-stream flow $5 \mathrm{~cm}$ above the bottom where feeding observations were made and water temperature were taken in highand low-flow habitats.

Observers were downstream of barnacles and barnacle feeding did not appear to be affected by their presence. We quantified the percentage of barnacles feeding in the field in 10 to 20 haphazardly selected small groups (25 to 50 ) of juveniles and adults in highand low-flow habitats during each observation period. Feeding was quantified at all sites and flow regimes in early June and July. In August and September feeding was quantified only at sites within Narragansett Bay due to time and logistic constraints. Qualitative observations of barnacle feeding were made every week at all study sites (June to September 1991) to supplement our rigorous quantification of feeding behavior.

Within- and between-population patterns in growth. Barnacle growth-rate variation within and among sites was examined by measuring the sizes of solitary individuals of a single year class (recruits) monthly from April to September 1991. Solitary individuals were defined as recruits not in physical contact with other barnacles. To ensure that the recruits we sampled were of approximately the same age, at each location and flow regime we cleared 4 areas of $1 \mathrm{~m}^{2}$ of all barnacles at intermediate $(+0.5 \mathrm{~m})$ tidal heights in the last week of March 1991. Since Semibalanus balanoides settlement stopped at all sites by the middle of April (Bertness et al. 1992), this provided a supply of recruits of similar ages at each site. Each month, ca 40 haphazardly selected recruits were collected from each site and flow regime. Solitary individuals were sampled to avoid confounding effects of crowding on recruit sizes (Barnes \& Powell 1950). Of these 40 recruits, 20 randomly selected individuals were measured (maximum basal diameter, $\pm 0.1 \mathrm{~mm}$ ) and soft tissue was separated from the shell and dried and weighed $( \pm 0.01 \mathrm{mg})$.
Within- and between-site barnacle recruitment and population dynamics. To examine within- and amongsite variation in population processes and particularly to test the hypothesis that within and among site variation in flow regimes affects barnacle population processes, we quantified recruitment and the densitydependent mortality of Semibalanus balanoides recruits at our study sites. In both 1990 and 1991, at each site (except Common Fence Point) we marked twenty $100 \mathrm{~cm}^{2}$ quadrats at intermediate tidal heights (+0.5 m) in low- and high-flow microhabitats in December before settlement. All barnacles were removed from the quadrats and a $5 \mathrm{~cm}$ border around each quadrat. Intermediate tidal heights were used to minimize barnacle mortality due to thermal stress and consumer pressure (Bertness 1989). Predatory snails were relatively rare at intermediate tidal heights at all sites, but to prevent these predators from influencing barnacle mortality in the quadrats we regularly removed all predatory snails found within $3 \mathrm{~m}$ of the quadrats. This effectively prevented any predatory snails from entering the quadrat areas. No other known barnacle predators were found at intermediate tidal heights at the sites. After $S$. balanoides settlement in April, barnacles in half of the quadrats at each site were thinned to low densities to limit crowding $<100$ recruits quadrat $^{-1}$; see Bertness 1989), and the quadrats were photographed. Quadrats were photographed again the following September, and barnacle survivorship was quantified as a function of site, density, and flow regime.

Data analysis. All data were analyzed using analysis of variance (ANOVA). For the flow tank experiment examining flow speed and temperature effects on feeding, arcsine-transformed feeding percentages were analyzed with a 3-way (age class $x$ flow speed $x$ temperature) repeated-measurement ANOVA. For the food concentration experiment, arcsine-transformed feeding percentages were analyzed with a 3-way (source population $\times$ age class $x$ water treatment) ANOVA.

Since chalk dissolution and chlorophyll concentration variation among sites was extremely consistent over time, the data were pooled by site and flow regime for analysis. Chalk dissolution was analyzed with a 2 -way (site $x$ exposure) ANOVA, while the chlorophyll data were analyzed with a 1-way (site) ANOVA.

Analysis of the field feeding data was complicated since we were unable to quantify feeding at all sites throughout the summer. Therefore, we analyzed arcsine-transformed data on the percentage of individuals feeding for only those months with data from all sites (June and July) with a 4 -way (site $x$ flow regime $\times$ age class $\times$ month) ANOVA. For analysis of all field data, 
site, flow regime, and age class were treated as fixed variables.

Barnacle size and recruitment data were analyzed with 3 -way (site $x$ flow regime $x$ time) repeated measurement ANOVA. Barnacle survivorship data (arcsine-transformed) were analyzed with a 4 -way (site $x$ flow regime $x$ density treatment $x$ year) ANOVA to examine annual variation in mortality among sites and flow regimes
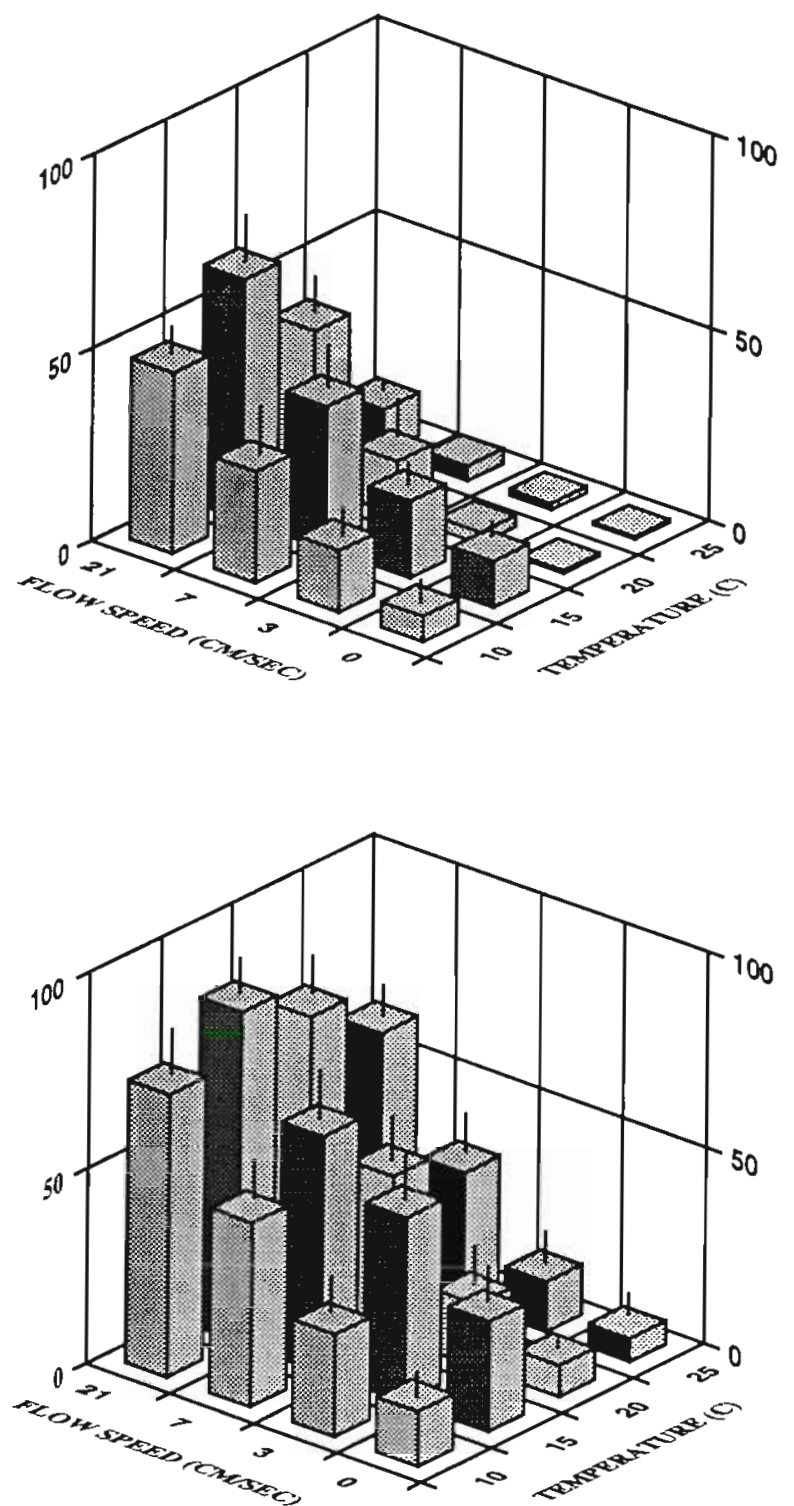

Fig. 2. Semibalanus balanoides. Effect of flow speed and water temperature on the feeding activity (average \% of individuals feeding) of temperature-acclimated barnacles under laboratory conditions. For each flow speed and temperature the data are the mean ( \pm SE) of 8 measurements on groups of adult ( $>14$ mo old) and juvenile $(<7$ mo old) individuals

\section{RESULTS}

Flow, temperature, and food concentration effects on barnacle feeding

Barnacle feeding activity was found to be strongly dependent on environmental conditions (Fig. 2). Barnacle feeding in the flow tank increased with increas. ing flow speed, peaked at intermediate temperatures, and juvenile barnacle feeding was nearly twice as high as adults at all flow speeds and temperatures ( $\mathrm{p}<$ 0.001 , multiple F-tests). Flow effects on feeding were similar at all temperatures $(\mathrm{p}>0.25$, flow speed $\times$ temperature interaction) and flow and temperature had similar effects on adult and juvenile feeding $(p>0.50$, flow $\times$ temperature $\times$ age class interaction).

All barnacle filter-feeding in the flow tank was passive rather than active except in still water (sensu Crisp \& Southward 1961). Even at low flow speeds, barnacle feeding was characterized by slow rhythmic cirral beats with no indication of rapid cirral beating to actively generate feeding currents.

Food concentration $(\mathrm{p}<0.0001, \mathrm{df}=2,185, F=$ $225)$, site of origin ( $p<0.0001$, df $=1,185, F=429$ ) and barnacle age $(\mathrm{p}<0.0001, \mathrm{df}=1,185, F=600)$ all directly affected barnacle feeding in the food concentration experiment (Fig. 3). Barnacle feeding activity increased with increased food concentrations, but feeding activity was always greater in Portsmouth water (full strength or dilute), suggesting that qualitative as well as quantitative differences in food supply influence feeding activity. Moreover, barnacles from Little Compton, a low food concentration site, fed much more actively than barnacles from Portsmouth, a high food concentration site, suggesting that feeding history influences feeding activity (Fig. 3). Food concentration effects on feeding, however, varied with both the site of origin of the barnacles (food concentration $\times$ site of origin interaction, $\mathrm{p}<0.006$, df $=$ $2,185, F=7.65$ ) and barnacle age (food concentration $x$ age interaction, $p<0.001, \mathrm{df}=2,185, F=24$ ). Adult barnacles from Little Compton responded to variation in food concentration more than barnacles from Portsmouth. Moreover, juveniles from both sites fed more frequently than adults, but age effects on feeding were more pronounced on Portsmouth than Little Compton barnacles (site of origin $\times$ age interaction, $\mathrm{p}<0.01, \mathrm{df}=1,185, F=10.0$ ). The 3 -way interaction among food concentration, site of origin, and barnacle age was also significant $(\mathrm{p}<0.001$, df $=2,185$, $F=54$ ). These complex interactions were due to differences in the magnitude of feeding responses only, since the qualitative effects of site of origin, food concentration, and barnacle age were always consistent (Fig. 3). 


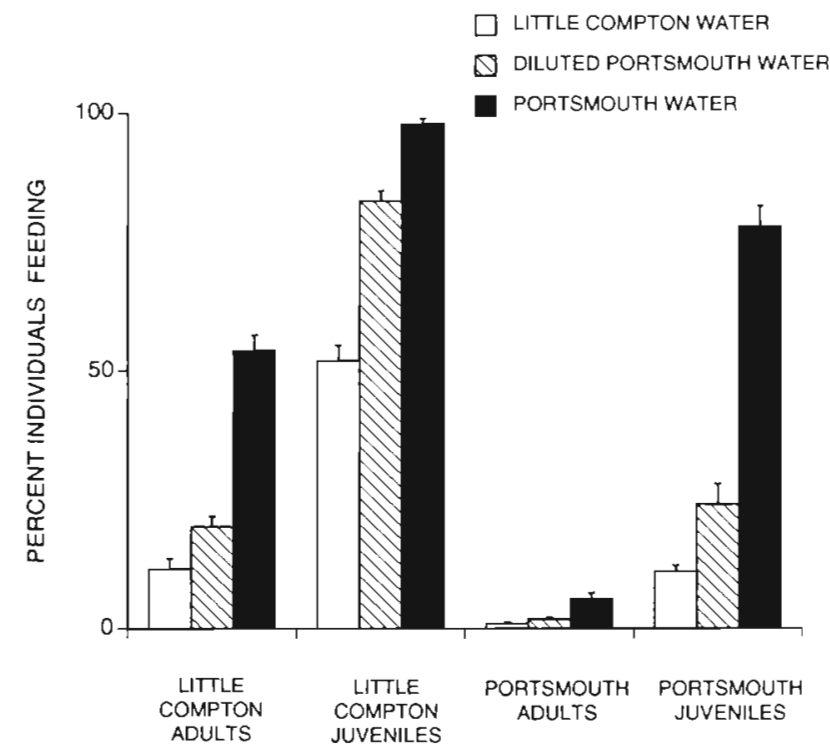

Fig. 3. Semibalanus balanoides. Effect of food concentration (water type) on barnacle feeding activity (average \% individuals feeding, $\mathrm{n}=8, \pm \mathrm{SE}$ ) under laboratory conditions. Barnacles from Little Compton and Portsmouth were examined in high production water from Portsmouth $\left(2.32 \pm 0.23 \mu \mathrm{g} \mathrm{l}^{-1}\right.$ chlorophyll a), Iow production water from Little Compton $\left(0.39 \pm 0.03 \mu \mathrm{g} \mathrm{l}^{-1}\right.$ chlorophyll a), and artificial low production. water (diluted) from Portsmouth $\left(1.18 \pm 0.03 \mu \mathrm{g} \mathrm{l^{-1 }}\right.$ chlorophyll a). All data were taken at a free-stream flow speed of $7 \mathrm{~cm} \mathrm{~s}^{-1}, 5 \mathrm{~cm}$ above the tank bottom

\section{Field site conditions}

Our field sites differed markedly in water characteristics (Figs. 4 \& 5). Water movement (chalk dissolution) differed among sites ( $\mathrm{p}<0.0001, \mathrm{df}=4,311, F=112$ ) and flow regimes within sites $(\mathrm{p}<0.001, \mathrm{df}=1,311, F=$ $210)$ without a site $x$ flow regime interaction ( $p>0.50$, $\mathrm{df}=4,311, F=0.5$ ). Mt. Hope had the lowest flows $(p<0.01$, Scheffé test), Common Fence Point ( $p<0.05$, Scheffé test), and Portsmouth ( $p<0.05$, Scheffé test) had successively higher flows, while flows at the open coast were the highest ( $p<0.01$, Scheffé test). Maximum free-stream flows directly measured at $\mathrm{Mt}$. Hope and Common Fence Point were 6 and $10 \mathrm{~cm} \mathrm{~s}^{-1}$, respectively, whereas, at Portsmouth maximum flows of 20 to $30 \mathrm{~cm} \mathrm{~s}^{-1}$ were commonly measured. Maximum flows measured at the open coast sites ranged from 20 to $40 \mathrm{~cm} \mathrm{~s}^{-1}$.

Chlorophyll concentrations ( $\mathrm{p}<0.01$, df $=4,128, F=$ $3.45)$ generally decreased from inland to open-coast locations (Fig. 4). Chlorophyll concentrations were similar ( $p>0.50$, Scheffé test) at Mt. Hope and Common Fence Point but dropped by nearly $50 \%$ ( $p<0.01$, Scheffé test) at Portsmouth. Open coast chlorophyll levels were half those of bay sites $(p<0.01$, Scheffé test each case).
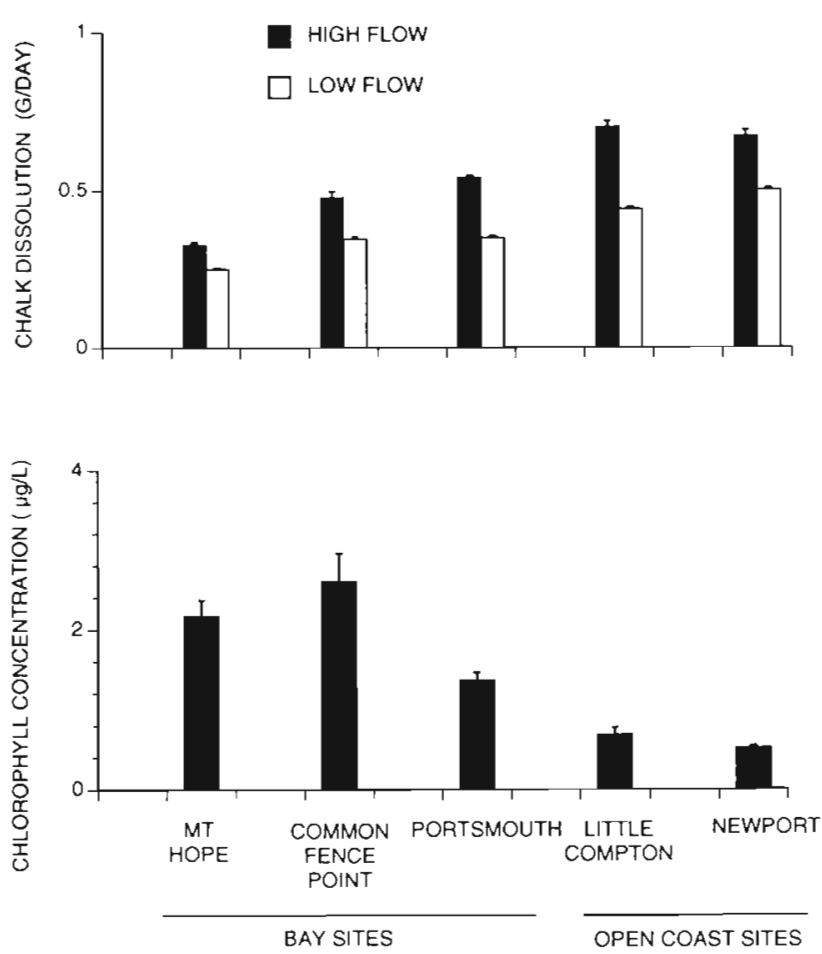

Fig. 4. Chalk dissolution and chlorophyll a data from the study sites. Data are pooled observations taken weekly from June to September 1991. For chalk dissolution, the data represent the mean ( $\pm \mathrm{SE}$ ) of 50 to 70 measurements in both high- and lowflow microhabitats. For the chlorophyll a data each bar is the mean of 40 to 50 measurements taken weekly $\left(n=4 \mathrm{wk}^{-1}\right)$ at each site

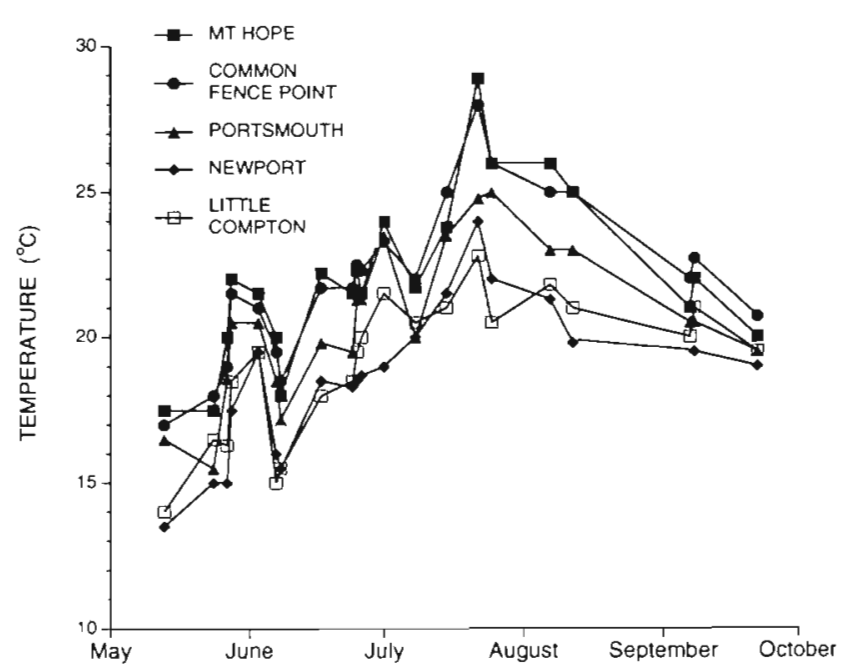

Fig. 5. Seasonal variation in water temperature among the field sites. Solid symbols = bay sites; open symbols = opencoast sites 
Water temperature differences between the bay and the open coast were also pronounced (Fig. 5). All sites showed seasonal increases in water temperature over the summer, but on the open coast water temperature never exceeded $24{ }^{\circ} \mathrm{C}$. In contrast, at the most inland sites (Mt. Hope and Common Fence Point), water temperatures generally exceeded $25^{\circ} \mathrm{C}$ from the middle of July to the middle of August with maximum temperatures reaching $29^{\circ} \mathrm{C}$ (Fig. 5).

\section{Field feeding patterns}

As in the laboratory, barnacle feeding in the field was entirely passive with no evidence of barnacles actively beating their cirri to generate feeding currents. Barnacle feeding, however, varied within and among sites as well as over tidal cycles in response to changes in free-stream flow speeds. Tidal cycle variation in feeding was usually more conspicuous in adults than juveniles. Whereas juvenile feeding generally remained relatively constant over a tidal cycle, adult feeding was usually elevated during incoming and outgoing tides when individuals experienced elevated (by 2 to 3 times) flow speeds (for a typical example see Fig. 6). This temporal variation in feeding, however, was small in comparison to within and among site spatial variation in feeding, so observations taken over tidal cycles were pooled (Fig. 7).

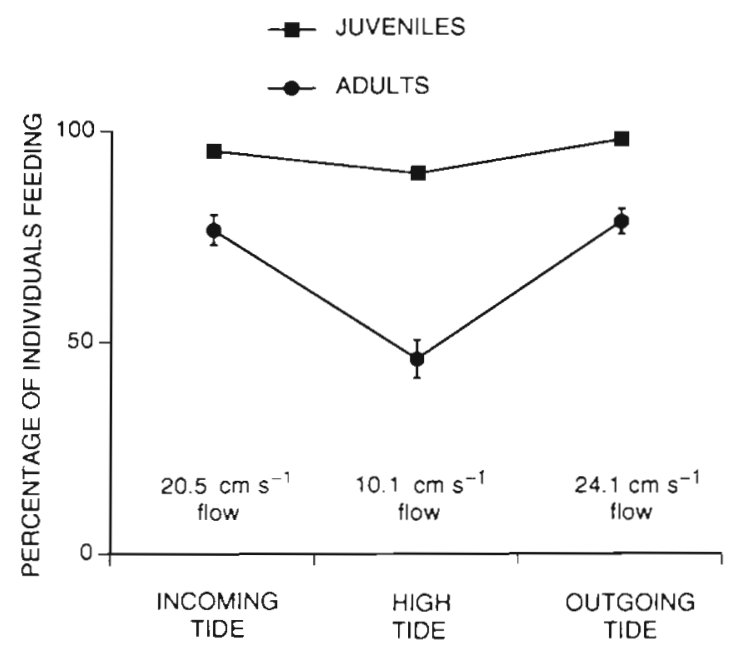

Fig. 6. Semibalanus balanoides. Typical example of tidal cycle variation in barnacle feeding activity (average $\%$ individuals feeding) from the Portsmouth site in August 1991 Each data point represents the mean ( $\pm \mathrm{SE}$ if larger than symbol) of 8 measurements. Whereas juveniles generally fed while submerged, adults fed most during the changing tide when flows were accelerated. Free-stream flow speed measured $5 \mathrm{~cm}$ above the bottom are also shown

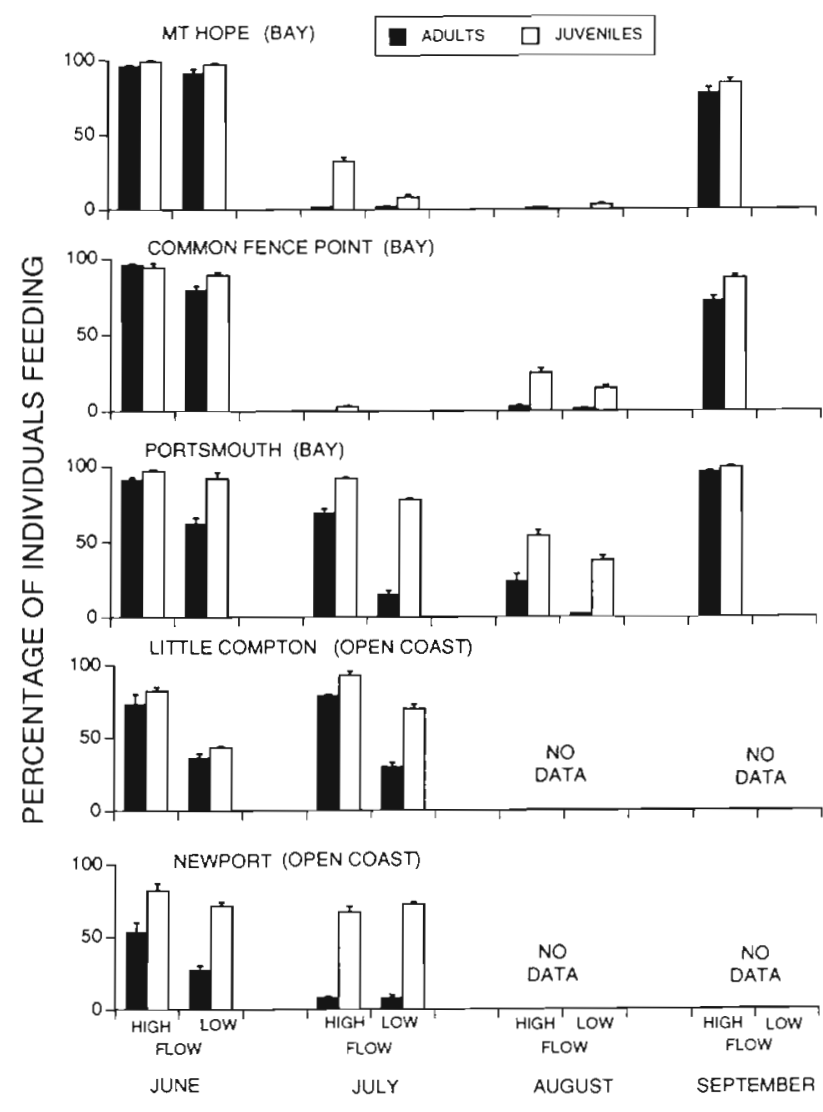

Fig. 7. Semibalanus balanoides. Barnacle feeding (average \% individuals feeding) from the 5 study sites. For each bar the data represent 24 independent measurements ( \pm SE), pooling data from rising, falling, and high tide. For analysis only data from June and July were considered since site coverage was incomplete in August and September

Within and among site variation in feeding was apparent in June and July when we have data for all sites. Age class ( $p<0.0001, \mathrm{df}=1,1355, F=362$ ), flow regime $(\mathrm{p}<0.0001, \mathrm{df}=1,1355, F=200)$ date $(\mathrm{p}<0.001, \mathrm{df}=1,1355, F=796)$, and site $(\mathrm{p}<0.001$, $\mathrm{df}=4,1355, F=90$ ), directly affected feeding. As in the laboratory, juvenile feeding percentages were higher than adult feeding percentages. Adult and juvenile feeding responded differently across sites $(\mathrm{p}<$ $0.0001, \mathrm{df}=4,1355, F=27$, age $\times$ site interaction), but not in different flow conditions $(\mathrm{p}>0.10$, df $=1,1355$, $F=2.4$, age $\times$ flow speed interaction). The feeding responses of adults and juveniles were qualitatively similar, but the magnitude of changes in adult feeding were larger than those in juvenile feeding. Differences between adult and juvenile feeding were generally accentuated at low food supply sites (e.g. Newport and Little Comptonj and low flow rates (Fig. 7). 
Semibalanus balanoides feeding in the field was also enhanced in high-flow habitats at each site, but the magnitude of flow enhancement of feeding varied across sites $(\mathrm{p}<0.0001, \mathrm{df}=4,21355, F=34$, flow $\times$ site interaction). Flow effects on feeding were generally greatest at sites with the highest flows and lowest food concentrations (e.g. Newport and Little Compton; Fig. 7).

The percentage of barnacles feeding also varied inconsistently among sites over time $(\mathrm{p}<0.0001, \mathrm{df}=$ $4,1355, F=319$, site $\times$ time interaction). This interaction was due to stronger seasonal variation in feeding at inland sites. Although feeding percentages at Mt. Hope and Common Fence Point were higher in June than at all other sites for juveniles and adults in both high-and low-flow habitats ( $p<0.05$, Scheffé test each case), by July feeding virtually stopped at Mt. Hope and Common Fence Point (Fig. 7). No other 2-, 3-, or 4way interactions among site, date, exposure, or age with the field feeding data were significant ( $p>0.10$ ).

Low feeding activity at inland sites in the summer was consistent with laboratory results predicting sharp reductions in feeding at high water temperatures and low flow speeds (Fig. 2). Virtually all of the feeding activity seen at the inland sites in July and August occurred during changing tides when the barnacles experienced increased flow speeds. At Portsmouth, where water temperatures were lower and flow speeds were higher, barnacle feeding remained high throughout the summer (Fig. 7). We tested the hypothesis that low summer feeding activity at inland sites was due to physical conditions of high temperatures and low flow speeds by exposing field barnacles to artificially enhanced flow speeds at high tide. In August, when only $4.5 \pm 1.1 \%(n=28$ counts $)$ of juveniles at Mt. Hope were feeding under natural conditions fflows $<2 \mathrm{~cm}$ $\mathrm{s}^{-1}$ ), we experimentally increased flow speeds by simply fanning barnacles with a diving flipper. Flow speeds were increased to 15 to $20 \mathrm{~cm} \mathrm{~s}^{-1}$ (measured $5 \mathrm{~cm}$ above the bottom) and feeding increased within $10 \mathrm{~s}$ by over an order of magnitude $(54.2 \pm 2.2 \%, \mathrm{n}=21$ counts). Feeding activity dropped to control levels less than 1 min after artificially enhanced flow speeds were stopped.

High levels of feeding resumed at all the bay sites in September when water temperatures dropped (Fig. 7), further supporting the hypothesis that midsummer feeding activity was inhibited at inland bay sites by high water temperatures.

At open-coast sites (Little Compton and Newport) barnacle feeding remained relatively constant over the entire summer (Fig. 7 and authors' qualitative observations). In August and September, weekly observations confirmed that barnacles on the open coast continued to feed actively throughout the summer.

\section{Variation in growth}

Juvenile shell diameters and soft tissue weights (Fig. 8) varied significantly among locations (diameters, $\mathrm{p}<0.01$, df $=1,1266, F=49$; weights, $\mathrm{p}<0.0001$, $\mathrm{df}=4,1266, F=73$ ), flow regimes (diameters: $p<0.01$, $\mathrm{df}=1,266, F=30$; weights: $\mathrm{p}<0.0001, \mathrm{df}=1,1266, F=$ 16.7), and over time (diameters: $\mathrm{p}<0.0001$, $\mathrm{df}=4,1266$, $F=3050$; weight: $p<0.0001$, df $=4,1266, F=884)$. Portsmouth barnacle sizes were substantially larger than those from any other site, and at all sites barnacles reached larger sizes in high-flow relative to lowflow microhabitats. Differences in both shell diameters ( $\mathrm{p}<0.0001, \mathrm{df}=4,1266, F=63$ ) and soft tissue weights ( $\mathrm{p}<0.0001, \mathrm{df}=4,1266, F=167)$ among sites varied significantly over time (site $\times$ time interaction), but no other 2- or 3-way interactions were significant $(\mathrm{p}>$ $0.10)$. By July recruits at Mt. Hope and Common Fence Point had basal diameters twice as large as at opencoast locations (Little Compton and Newport). The diameter of inland barnacles, however, did not increase over the rest of the summer $(p>0.10$, Scheffé

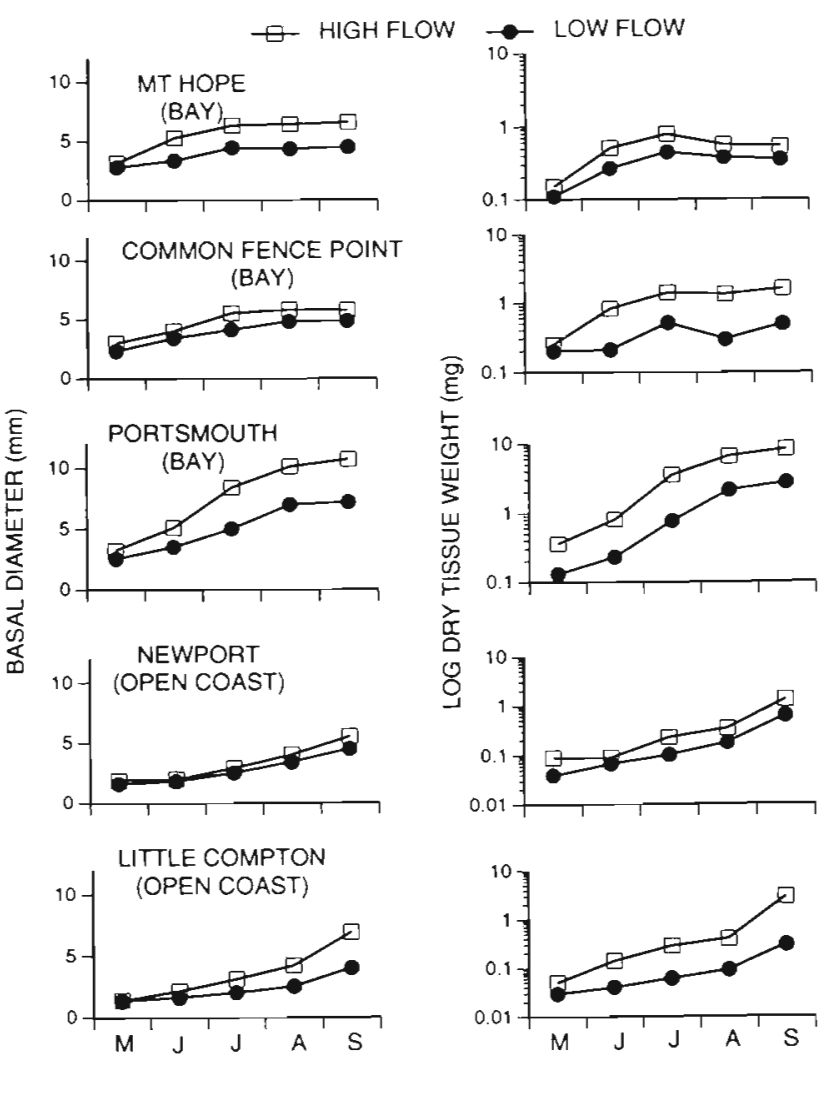

Fig. 8. Semibalanus balanoides. Recruit sizes from study sites in high- and low-flow microhabitats. Each point represents the mean of 20 measurements. Error bars (SE) are not shown since they are smaller than the symbols 
test all cases). This lack of growth paralleled the seasonal decline in feeding at these sites when temperatures exceeded $25^{\circ} \mathrm{C}$. In contrast, recruits from the open coast continued to grow and by September were as large or larger than their inland counterparts (Fig. 8).

Differences in soft-tissue growth among sites were even more pronounced (Fig. 8). At Mt. Hope and Common Fence Point, tissue weights increased in the spring and by July were 2 to 4 times higher than comparable open-coast barnacles. In August and September, however, tissue weights of inland barnacles remained constant or declined, suggesting that without feeding they were expending soft tissue reserves. This was in sharp contrast to the continued tissue growth of open-coast juveniles (Fig. 8). By September in high-flow habitats, tissue weights of open-coast recruits equaled or exceeded those at inland sites.

Growth rates at Portsmouth, where feeding activity continued throughout the summer and chlorophyll concentrations were relatively high, were remarkably higher than at all other sites (Fig. 8). By September, Portsmouth recruits in high-flow habitats had softtissue weights 3 to 18 times higher than barnacles in all other locations.

\section{Variation in local barnacle population dynamics}

Semibalanus balanoides recruitment (Table 1) varied by over an order of magnitude among sites ( $\mathrm{p}<$ 0.0001 , $\mathrm{df}=3,144, F=413$ ) and was enhanced in highflow microhabitats within sites $(p<0.0001$, $\mathrm{df}=1,144$, $F=1529$ ). Year did not directly influence recruitment ( $p>0.10, \mathrm{df}=1,144, F=1.7$ ), but site differences in recruitment varied strongly among years $(\mathrm{p}<0.0001$, $\mathrm{df}=3,144, F=780$, site $\times$ year interaction). Recruitment within Narragansett Bay (Mt. Hope and Portsmouth) was higher in 1990 than in 1991 whereas on the open coast (Little Compton and Newport) recruitment was higher in 1991 than 1990. These differences in recruitment reflect corresponding differences in larval densities (Gaines \& Bertness 1993) and annual differences in bay flushing and larval transport out of the bay (Gaines \& Bertness 1992) and are discussed elsewhere.

Recruitment was also enhanced in high-flow microhabitats, but flow effects on recruitment varied among sites and years $(\mathrm{p}<0.001$, df $=3,144, F=141$; flow $\times$ site, flow $\times$ year, and flow $\times$ site $\times$ year interactions $)$. The qualitative pattern was always the same - highflow microhabitats always had a higher number of recruits than low-flow microhabitats. The magnitude of the enhancement of recruitment in high-flow microhabitats, however, varied among sites and years, hence the significant statistical interaction (Table 1).
Table 1. Semibalanus balanoides. Recruitment densities (recruits $100 \mathrm{~cm}^{-2}$ ) measured in early April immediately after settlement ceased in high-and low-flow habitats at the study sites in 1990 and 1991. All data are from intermediate tidal heights $(+0.5 \mathrm{~m})$ and are the mean of ten $10 \times 10 \mathrm{~cm}$ quadrats site $^{-1}$ flow regime ${ }^{-1}$

\begin{tabular}{|c|c|c|c|}
\hline Location & Year & Microhabitat & $\begin{array}{l}\text { Recruit density } \\
\quad(x \pm \mathrm{SE})\end{array}$ \\
\hline \multirow[t]{4}{*}{ Mt. Hope } & \multirow[t]{2}{*}{1990} & High flow & $2024 \pm 220$ \\
\hline & & Low flow & $560 \pm 108$ \\
\hline & \multirow{2}{*}{1991} & High flow & $348 \pm 28$ \\
\hline & & Low flow & $16.6 \pm 14$ \\
\hline \multirow{4}{*}{ Portsmouth } & \multirow{2}{*}{1990} & High flow & $1836 \pm 127$ \\
\hline & & Low flow & $1310 \pm 84$ \\
\hline & \multirow[t]{2}{*}{1991} & High flow & $815 \pm 58$ \\
\hline & & Low flow & $660 \pm 47$ \\
\hline \multirow[t]{4}{*}{ Little Compton } & \multirow[t]{2}{*}{1990} & High flow & $1216 \pm 138$ \\
\hline & & Low flow & $908 \pm 80$ \\
\hline & \multirow{2}{*}{1991} & High flow & $3598 \pm 250$ \\
\hline & & Low flow & $1052 \pm 116$ \\
\hline \multirow[t]{4}{*}{ Newport } & \multirow[t]{2}{*}{1990} & High flow & $1336 \pm 72$ \\
\hline & & Low flow & $1108 \pm 79$ \\
\hline & \multirow[t]{2}{*}{1991} & High flow & $2093 \pm 216$ \\
\hline & & Low flow & $1395 \pm 124$ \\
\hline
\end{tabular}

Barnacle mortality at the field sites (Fig. 9) differed among densities ( $p<0.0001$, $d f=1,225, F=181$ ), flow microhabitats ( $\mathrm{p}<0.001$, df $=1,225, F=97$ ), and sites $(\mathrm{p}<0.001, \mathrm{df}=3,225, F=244)$, but not years $(\mathrm{p}>0.25$,

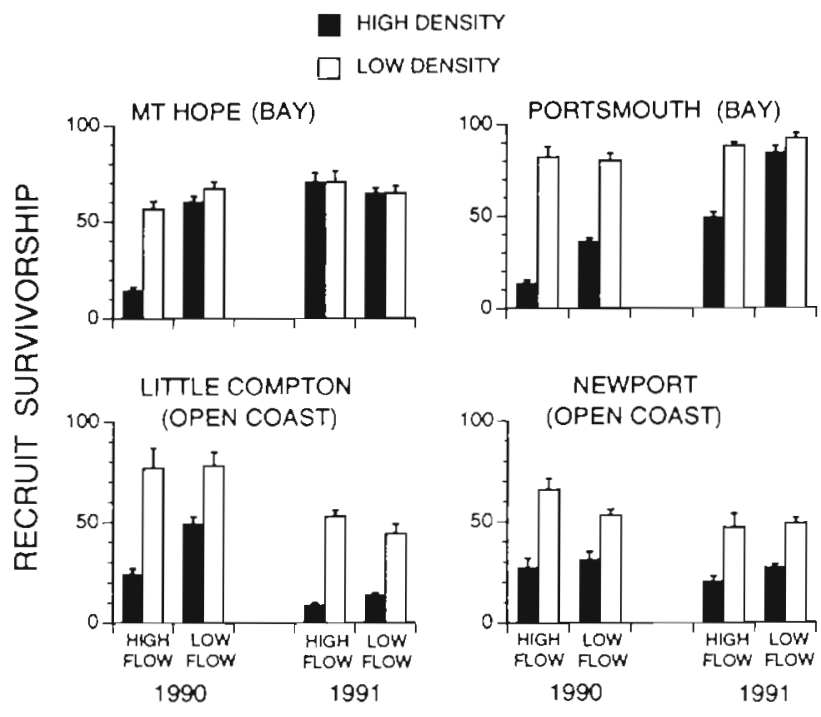

Fig. 9. Semibalanus balanoides. Recruit survivorship at natural and thinned $\left(<2\right.$ ind. $\left.\mathrm{cm}^{-2}\right)$ densities in high- and lowflow microhabitats at the study sites in 1990 and 1991. Each bar represents the mean $( \pm \mathrm{SE})$ of 8 to 10 replicate quadrats 
$\mathrm{df}=1,225, F=0.8$ ). Recruit mortality was generally higher at high densities than at low densities, and higher in high-flow than in low-flow microhabitats reflecting intensified density-dependent mortality at high recruit densities and growth rates. The magnitude of these effects, however, varied markedly among years $(p<0.001$, $d f=1,255, F=164$, year $\times$ density interaction; $\mathrm{p}<0.0001, \mathrm{df}=1,225, F=26$, year $\times$ flow interaction) and sites ( $p<0.0001, \mathrm{df}=2,225, F=20$, site $x$ flow interaction; $\mathrm{p}<0.001$, df $=3,225, F=107$, site $x$ density interaction; $\mathrm{p}<0.0001, \mathrm{df}=3,225, F=281$, site $x$ year interaction) largely as a consequence of site and year variation in recruit densities (Table 1). Within Narragansett Bay, for example, recruit mortality at high densities was generally higher in 1990 than in 1991 reflecting the high recruit densities in 1990. All 3-way and 4-way interactions among sites, densities, years and flow microhabitat, however, were also significant ( $\mathrm{p}<0.001$, all cases).

To visualize the nature of the key interactions among sites and flow microhabitats, in Fig. 10 the recruit survivorship data are plotted as a function of initial recruit density pooling data from each site and flow microhabitat. At sites within Narragansett Bay (Mt. Hope and Portsmouth) density-dependent mortality was apparent in both high-and low-flow microhabitats, but was
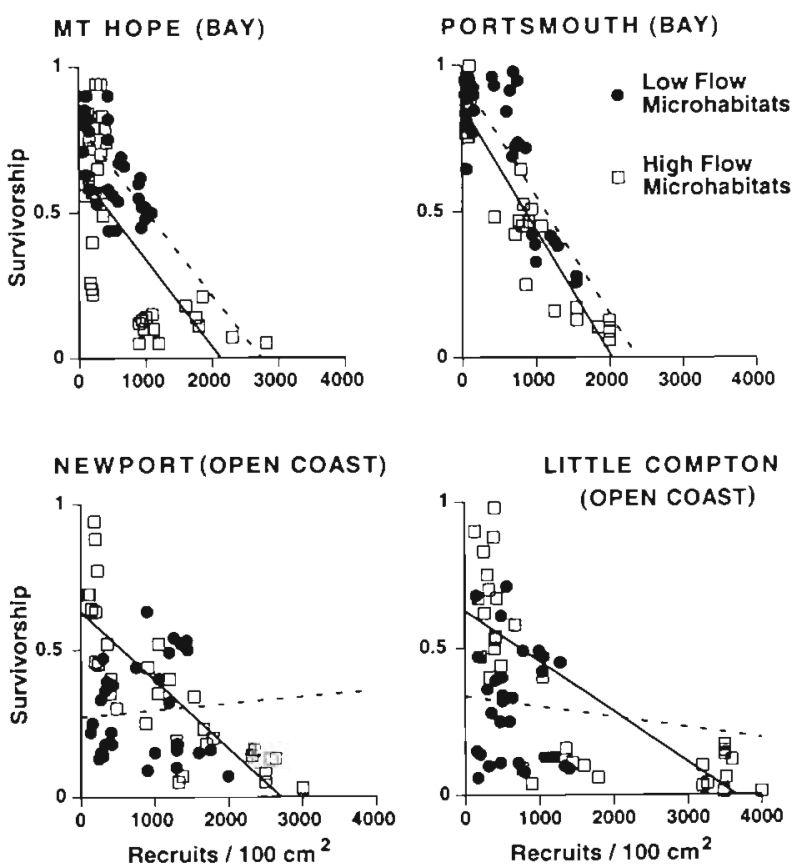

Fig. 10. Semibalanus balanoides. Survivorship of recruits in high-and low-flow microhabitats at the study sites as a function of recruitment density. Data are pooled from 1990 and 1991. Lines are best-fit linear regressions for high- (-) and low-flow (- - ) microhabitats more severe at high than low flow speeds. In high-flow habitats at these sites accelerated growth rates led to increased barnacle crowding, hummock formation, and subsequent barnacle mortality in comparison to low-flow microhabitats with lower growth rates. In contrast, at the open-coast sites (Newport and Little Compton), density-dependent mortality was only apparent in high-flow microhabitats where growth rates were the highest. In low-flow microhabitats at the open-coast sites, barnacle crowding and densitydependent mortality appeared to be minimized by low growth rates (Fig. 8).

\section{DISCUSSION}

Our results suggest that the feeding, growth, and population dynamics of acorn barnacles are tightly coupled to water column characteristics and that variation in free-stream flow speeds and food concentrations may leave strong signatures on benthic populations.

\section{Acorn barnacle feeding}

Barnacle feeding has previously been shown to be sensitive to variation in flow and food concentrations in the laboratory (for review see Anderson \& Southward 1987). Previous work, however, focused exclusively on how physical conditions influence how barnacles feed (i.e. cirral beat frequency). We have focused on when rather than how barnacles feed. We found that Semibalanus balanoides feeding activity increased with both flow speed (Fig. 2) and food concentrations (Fig. 3), suggesting that barnacles feed most when the delivery of food is high. In contrast, barnacle feeding decreased with increasing body size and at high temperatures (Fig. 2), indicating that feeding decisions are also mediated by metabolic demands. Metabolic rates in poikilothermic organisms are known to decrease with increasing body size (Prosser 1973) which may explain the decreased feeding activity observed in larger barnacles in the laboratory and field (Figs. 2 \& 7). Moreover, reduced feeding at high temperatures would be predicted if increased temperatures elevate metabolic rates and feeding costs. This suggests that barnacle feeding may be dictated by a simple cost/benefit balance. Water temperature and body size may dictate metabolic demands and set the baseline cost of feeding. Food concentrations and delivery rates appear to dictate feeding benefits and lead to increased barnacle feeding at high flow speeds (Fig. 2) and food concentrations (Fig. 3). 


\section{Water column effects on growth and population dynamics}

Variation in barnacle feeding in the field responded to variation in flow speed and temperature as predicted by our laboratory studies. Moreover, variation in barnacle feeding in the field was directly reflected in field growth-rate patterns. Individuals exposed to high flow speeds both within and among sites fed more frequently and grew to larger sizes than individuals exposed to low flow speeds (Fig. 8). Moreover, temperature effects on feeding were also apparent and led to among-site variation in barnacle feeding and growth. At inland sites, where high temperatures led to reduced feeding during the summer months, shell growth stopped and soft-tissue weights decreased likely reflecting the utilization of stored energy reserves (Fig. 8). In contrast, in open-coast habitats where temperature remained relatively low, barnacles continued to feed and grow throughout the summer.

Among-site variation in barnacle growth led to extreme variation in the size of recruits both within and among sites (Fig. 8). At Portsmouth, for example, recruits exposed to high flow speeds, high food levels, and moderate temperatures grew to over $10 \mathrm{~mm}$ in basal diameter with dried-tissue weights of nearly $9 \mathrm{mg}$. In contrast, Little Compton recruits exposed to low flow speeds and food concentrations grew to less than $4 \mathrm{~mm}$ in basal diameter and $0.26 \mathrm{mg}$ dried tissue body weight. This order of magnitude variation in growth can lead to extreme variation in reproductive output within and among populations (Bertness et al. 1991) that may have strong effects on the supply and source of future recruits.

Increased growth rates can also potentially influence the density-dependent dynamics of barnacles by accelerating individual crowding, hummock formation, and mortality (Bertness 1989). Density-dependent mortality of barnacles, however, is dictated by both growth rates and recruitment densities (Barnes \& Powell 1950). Since high flow speeds can enhance recruitment by increasing the flux of potential settlers to a site (Table 1, see also Gaines \& Bertness 1993), and increase growth by increasing food fluxes, flow can have much more dramatic effects on filter-feeding benthic populations than the effects of variable recruitment or growth rates alone would predict. While our examination of within- and among-site variation in the dynamics of Semibalanus balanoides did not experimentally evaluate the roles of other biotic (e.g. predation) and physical (e.g. heat and desiccation) factors on $S$. balanoides dynamics, the results strongly suggest that flow-speed variation can dramatically influence barnacle population dynamics. At both sites exposed to high flows (e.g. Portsmouth) and high-flow microhabitats within sites, we consistently found increased $S$. balanoides settlement (Table 1), growth (Fig. 8), and accelerated density-dependent mortality (Figs. $9 \& 10$ ). We monitored $S$. balanoides population dynamics at intermediate tidal heights to minimize the predation (Connell 1972, Menge 1976) and physical stress (Wethey 1983, Bertness 1989) mortality common at lower and higher tidal heights respectively. While these other factors likely often override the influence of crowding on barnacle population dynamics at higher and lower tidal heights, our results strongly suggest that the synergism between flow enhancement of settlement and food supply potentially has dramatic consequences on patterns of barnacle densitydependent dynamics.

\section{Flow speed, food supply and population dynamics of sessile filter feeders}

While we examined barnacles, our results likely apply to passive filter-feeding organisms in general, and imply that benthic organisms may be more tightly coupled to oceanographic conditions than is generally appreciated (also see Sebens 1984, Eckman et al. 1989a).

Recently, considerable attention has been given to the role of larval supply in dictating marine invertebrate populations (e.g. Hawkins \& Hartnoll 1982, Roughgarden et al, 1987, Shanks \& Wright 1987 , Underwood \& Fairweather 1989, Sale 1990). This work has suggested that larval dynamics can often be driven by oceanographic conditions. Upwelling (Roughgarden et al. 1988) and embayment flushing (Gaines \& Bertness 1992) can dictate geographic patterns in larval recruitment and affect the distribution and abundance of adults. At smaller spatial scales, fluid dynamics can also influence settlement patterns (Eckman 1983, Butman 1987, Mullineaux \& Butman 1990). Recruitment effects, however, may be only part of the role played by water column features in shaping benthic marine assemblages.

Oceanographic features that affect larval recruitment often also influence the feeding and growth of benthic filter feeders. For passive filter-feeding organisms, in particular, this synergism may often magnify the effects of oceanographic processes on populations. If habitats exposed to high flows typically have enhanced recruitment and growth rates, the signature of oceanographic condition on benthic invertebrate assemblages may be substantial.

Oceanographic features that influence the recruitment and secondary production of sessile filter feeders are also likely to trigger cascading effects on the structure of marine assemblages. For example, since species of filter feeders may be differentially influenced by 
flow speed (Walne 1972, LaBarbera 1984), oceanographic features that influence fluid dynamics may dictate the outcome of competitive interactions among filter feeders. Moreover, conditions that support increased secondary production are also likely to support larger and potentially more diverse consumer populations (Connell \& Orias 1964, Sanders 1968).

Understanding these linkages between water column and benthic processes will require taking a broad geographic approach to studying marine populations, but could greatly enhance our understanding of process and pattern in marine assemblages.

\section{LITERATURE CITED}

Anderson, D. T., Southward, A. J. (1987). Cirral activity of barnacles. In: Southward, A. J. (ed.) Barnacle biology. Bakeman Press, Rotterdam, p. 135-174

Barnes, H., Powell, H. T. (1950). The development, general morphology, and subsequent elimination of barnacle populations after a heavy initial settlement. J. Anim. Ecol. 19: 175-179

Bertness, M. D. (1989). Positive and negative density-dependent mortality and the population structure of Semibalanus balanoides in a sheltered bay habitat. Ecology 70: $257-268$

Bertness, M. D., Gaines, S. D., Bermudez, D., Sanford, E. (1991). Extreme spatial variation in the growth and reproductive output of the acorn barnacle Semibalanus balanoides. Mar. Ecol. Prog. Ser. 75: 91-100

Bertness, M. D., Gaines, S. D., Stephens, E., Yund, P. (1992). Components of recruitment in populations of the acorn barnacle, Semibalanus balanoides. J. exp. mar. Biol. Ecol. 156: $199-215$

Best, B. A. (1988). Passive suspension feeding in a sea pen: effects of ambient flow on volume flow rate and feeding efficiency. Biol. Bull. 175: 332-342

Bos, M., Harmens, H., Brieling, K. (1986). Gene flow in Plantago. I. Gene flow and neighborhood size in P. lanceolata. Hered. 56: 43-54

Butman, C. A. (1987). Larval settlement in soft-sediment invertebrates: the spatial scales of pattern explained by active habitat selection and the emerging role of hydrodynamical processes. Oceanogr. mar. Biol. A. Rev. 25: $113-116$

Cancino, J. M., Hughes, R. N. (1987). The effect of water flow on growth and reproduction of Celleporella hyalina (L.) (Bryozoa: Cheilostomata). J. exp. mar. Biol. Ecol. 112 $109-130$

Connell, J. H. (1961). The influence of interspecific competition and other factors on the distribution of the barnacle Chthamalus stellatus. Ecology 42: 710-723

Connell, J. H. (1972). Community interactions on marine rocky intertidal shores. A. Rev. Ecol. Syst. 3: 169-192

Connell, J. H., Orias, E. (1964). The ecological regulation of species diversity. Am. Nat. 98: 399-414

Crisp, D. J. (1960). Factors influencing growth rate in Balanus balanoides. J. Anim. Ecol. 25: 95-116

Crisp, D. J., Southward, A. J. (1961). Different types of cirral activity of barnacles. Phil. Trans. R. Soc. 243: 271-308

Day, J. W., Hall, C. A. S., Kemp, W. M., Yanez-Arancibia, A. (1989). Estuarine ecology. John Wiley and Sons, New York

Denny, M. W. (1988). Biology and mechanics of the waveswept environment. Princeton University Press, Princeton
Eckman, J. (1983). Hydrodynamic processes affecting benthic recruitment. Limnol. Oceanogr. 28: 241-252

Eckman, J., Duggins, D. O., Sewell, A. T. (1989a). Ecology of understory kelp environments. I. Effects of kelps on flow and particle transport near the bottom. J exp. mar. Biol. Ecol. 129: 173-187

Eckman, J. G., Peterson, C. H., Cahalan, J. A. (1989b). Effects of flow speed, turbulence, and orientation on growth of juvenile bay scallops Argopectin irradians. J. exp. mar. Biol. Ecol. 132: 123-140

Fenner, M. (1985). Seed ecology. Chapman Hall, London

Fréchette, M., Butman, C. A., Geyer, W. R. (1989). The importance of boundary-layer flows in supplying phytoplankton to the benthic suspension feeder, Mytilus edulis (L.) Limnol. Oceanogr. 34(1): 19-36

Gaines, S. D., Bertness, M. D. (1992). Dispersal of juveniles in sessile marine species. Nature 360: 579-580

Gaines, S. D., Bertness, M. D. (1993). Measuring the connection between dispersal and population dynamics: why ecologists must learn to integrate. Ecology (in press)

Gaines, S. D., Roughgarden, J. (1985). Larval settlement rate: a leading determinant of structure in an ecological community of the marine intertidal zone. Proc. natl. Acad. Sci. USA 82: 3707-3711

Gambi, M. C., Nowell, A. R. M., Jumars, P. A. (1990). Flume observations on flow dynamics in Zostera marina (eelgrass) beds. Mar. Ecol. Prog. Ser. 61: 159-169

Geiger, R. (1971). Climate near the ground, 4th edn. Harvard University Press, Cambridge, MA

Grizzle, R. E., Morin, P. J. (1989). Effects of tidal currents, seston, and bottom sediments on growth of Mercenaria mercenaria: a field experiment. Mar. Biol. 102: 85-93

Hatton, H. (1938). Essais de bionome explicative sur quelques espèces intercotidales. Annls Inst. océanogr. Monaco (N.S.) 17: 241-348

Hawkins, S. J., Hartnoll, R. G. (1982). Settlement patterns of Semibalanus balanoides in the Isle of Man. J. exp. mar. Biol. Ecol. 62: 272-283

Irlandi, E. A., Peterson, C. H. (1991). Modification of animal habitat by large plants: mechanisms by which seagrasses influence clam growth. Oecologia 87: $307-318$

Jackson, J. B. C. (1979). Morphological strategies of sessile animals. In: Larwood, G., Rosen, B. R. (eds.) Biology and systematics of colonial organisms. Academic Press, London, p. 499-555

LaBarbera, M. (1984). Feeding currents and particle capture mechanisms in suspension feeding animals. Am. Zool. 24: $71-84$

Menge, B. A. (1976). Organization of the New England rocky intertidal community: role of predation, competition, and environmental heterogeneity. Ecol. Monog. 46: 355-393

Mullineaux, L., Butman, C. A. (1990). Recruitment of encrusting benthic invertebrates in boundary-layer flows: a deepwater experiment on Cross Seamount. Limnol. Oceanogr. 35: $409-423$

Muschenheim, D. K. (1987a). The role of hydrodynamic sorting of seston in the nutrition of a benthic suspension feeder, Spia setosa. Biol. Oceanogr. 4(3): 265-288

Muschenheim, D. K. (1987b). The dynamics of near-bed seston flux and suspension-feeding benthos. J. mar. Res. 45 $473-496$

Nowell, A. R. M., Jumars, P. (1984). Flow environments of aquatic benthos. A. Rev. Ecol. Syst. 15: 303-328

Okamura, B. (1984). The effects of ambient flow velocity, colony size, and upstream colonies on the feeding success of Bryozoa. I. Bugula stolonifera Ryland, an arborescent species. J. exp. mar. Biol. Ecol. 83:179-193 
Okamura, B. (1992). Microhabitat variation and patterns of colony growth and feeding in a marine bryozoan. Ecology $74(4): 1502-1513$

Opdyke, B. N., Vust, G., Ledwell, J. R. (1987). Mass transfer from smooth alabaster surfaces in turbulent flows. Geophys. Res. Lett. 14: 1131-1134

Pawlik, J. R., Butman, C. A., Starczak, V. R. (1991). Hydrodynamic facilitation of gregarious settlement of a reefbuilding tube worm. Science 251: 421-424

Peterson, C. H., Summerson, H. C., Duncan, P. B. (1984). The influence of seagrass cover on population structure and individual growth rate of a suspension-feeding bivalve, Mercenaria mercenaria. J. mar. Res. 42: 123-138

Peterson, C. H., Black, R. (1987). Resource depletion by active suspension feeders on tidal flats: influence of local density and tidal elevation. Limnol. Oceanogr. 32: 143-166

Prosser, C. L. (1973). Comparative animal physiology. W. B. Saunders, Philadelphia

Roughgarden, J. S., Gaines, S. D., Pacala, S. (1987). Supply side ecology: the role of physical transport processes. In: Organization of communities: past and present. Proc. Brit. Ecol. Soc. Blackwell Scientific Publications, London, p. $459-489$

Roughgarden, J. S., Gaines, S. D., Possingham, H. (1988). Recruitment dynamics in complex life cycles. Science 241 : $1460-1466$

Sale, P. (1990). Supply side ecology: is the bandwagon moving in the right direction? Trends Ecol. Evol. 5(1): 25-27

Sanders, H. L. (1968), Marine benthic diversity: a comparative study. Am. Nat. 102: 243-292

Sebens, K. P. (1984). Water flow and coral colony size: interhabitat comparisons of the octocoral Alcyonium siderium. Proc. natl. Acad. Sci. USA 81: 5473-5477

Shanks, A. L., Wright, W. G. (1987). Internal wave mediated shoreward transport of cyprids, megalopae, gammarids and correlated longshore differences in the settling rate of intertidal barnacles. J. exp. mar. Biol. Ecol. 114: 1-13

This article was presented by R. H. Karlson, Newark, Delaware, USA
Shimeta, J., Jumars, P. A. (1991). Physical mechanisms and rates of particle capture by suspension feeders. Oceanogr. mar. Biol. A. Rev. 29: 191-257

Southward, A. J. (ed.) (1987). Barnacle biology. A. A. Balkema, Rotterdam

Strickland, J. D. H., Parsons, T R. (1968). A practical manual of seawater analysis. Bull. Fish. Res. Bd Can. 167

Tonsor, S. (1985). Intrapopulation variation in pollen-mediated gene flow in Plantago lanceolata. Evolution 39(4) $775-782$

Trager, G. C., Hwang, J. S., Strickler, J. R. (1990). Barnacle suspension-feeding in variable flow. Mar. Biol. 105: $117-127$

Underwood, A. J, Fairweather, P. G. (1989). Supply-side ecology and benthic marine assemblages. Trends Ecol. Evol. 41(1): $16-19$

Valiela, I. (1984). Marine ecological processes. SpringerVerlag, New York

Vogel, S. (1981). Life in moving fluids. Princeton University Press, Princeton

Vogel, S., LaBarbera, M. (1978). Simple flow tanks for research and teaching. BioSci. 28: 638-643

Walne, P. R. (1972). The influence of current speed, body size, and water temperature on the filtration rate of five species of bivalves. J. mar. biol. Ass. U.K. 52: 345-374

Wethey, D. S. (1983). Geographical limits and local zonation: the barnacles Semibalanus and Chthamalus in New England. Biol. Bull. 165: 330-341

Wildish, D. J., Peer, D. (1983). Tidal current speed and production of benthic macrofauna in the lower Bay of Fundy. Can. J. Fish. Aquat. Sci. 40: (Suppl. 1): 309-321

Wildish, D. J., Kristmanson, D. D. (1979). Tidal energy and subtidal macrobenthic animals in estuaries. J. Fish. Res. Bd Can. 36: 1197-1206

Yund, P. O., Gaınes, S. D., Bertness, M. D. (1991). Cylindrical tube traps for larval sampling. Limnol. Oceanogr. 36(6): $1167-1177$

Manuscript first received: April 4, 1993

Revised version accepted: October 4, 1993 